Article

\title{
Is Trade Credit a Sustainable Resource for Medium-Sized Italian Green Companies?
}

\author{
Maria Cristina Arcuri ${ }^{1, *}$ and Raoul Pisani ${ }^{2}$ \\ 1 Department of Economics and Management, University of Florence, 50121 Florence, Italy \\ 2 Department of Economics and Management, University of Trento, 38122 Trento, Italy; raoul.pisani@unitn.it \\ * Correspondence: mariacristina.arcuri@unifi.it
}

Citation: Arcuri, M.C.; Pisani, R. Is Trade Credit a Sustainable Resource for Medium-Sized Italian Green Companies?. Sustainability 2021, 13, 2872. https://doi.org/10.3390/ su13052872

Academic Editor: Matteo Rossi

Received: 30 January 2021

Accepted: 2 March 2021

Published: 7 March 2021

Publisher's Note: MDPI stays neutral with regard to jurisdictional claims in published maps and institutional affiliations.

Copyright: (c) 2021 by the authors. Licensee MDPI, Basel, Switzerland. This article is an open access article distributed under the terms and conditions of the Creative Commons Attribution (CC BY) license (https:// creativecommons.org/licenses/by/ $4.0 /)$.

\begin{abstract}
Medium-sized Enterprises (MEs) are a limited number of Small and Medium-sized Enterprises (SMEs) in EU-28 countries, but they contribute greatly to value added and employment. They are also key to pursuing sustainable local development in terms of green economic growth. Because trade credit is a crucial financial source for SMEs, this article investigates the importance of trade credit for Italian MEs, and particularly for 'green' MEs, rather than 'non-green' MEs. A panel analysis is applied to 101,250 observations over the period 2010-2019. We find that green MEs rely more on trade credit than non-green MEs. Moreover, trade credit is more important for younger, smaller, less profitable, and less liquid MEs. We further show that a substitution effect between trade and banking credit exists, and that the local development level affects the demand for trade credit. Our results demonstrate that trade credit supports sustainable development more than banking credit. Financial intermediaries should therefore include green parameters in the assessment of the creditworthiness of MEs, and policymakers should consider that trade credit and financial inclusion may be important in pursuing sustainable local development and economic growth.
\end{abstract}

Keywords: account payable and receivable; green economy; firm age; industry in the strict sense; local development; medium enterprise (ME); trade credit

\section{Introduction}

The concept of sustainable development was introduced at the beginning of the 1980s [1], and was resumed and deepened by the United Nations in the second part of the 1980s [2]. According to the World Commission on Environment and Development (WCED), sustainable development is "development that meets the needs of the present without compromising the ability of future generations to meet their own needs". It was further explored in the UK at the end of decade [3]. After the adoption of Agenda 21 (in 1992, at the Rio United Nations Conference on Environment and Development-UNCED) central and local governments started to adopt some kinds of regulations preventing environmental/ecological degradation [4,5]. However, it was after the 2008 crisis that the debate focused on a 'Global Green New Deal' [6] as a program that aimed to stimulate economic recovery, and at the same time improve the sustainability of the world economy (reducing carbon dependency, protecting ecosystems and water resources, and alleviating poverty). In the following years, authorities and academics proposed different notions of the green economy $[7,8]$, and in recent years, EU policy has placed great emphasis on the green economy. The EU's vision $[9,10]$ relies on economic aspects (resource efficiency, together with sustainable consumption and production patterns), environmental components (the preservation of natural capital, investments in natural resources, and climate change mitigation policies), and social policies (human well-being, decent jobs, the reduction of inequalities, and tackling poverty) [2]. The EU defines the 'green economy' as an "economy that can secure growth and development, while at the same time improving human well-being, providing decent jobs, reducing inequalities, tackling poverty and preserving the natural capital upon which we all depend" (European Commission 'Rio + 
20: towards the green economic and better performance', Communication 2011). Empirical investigations in the EU have showed that the green economy can effectively create new sources of growth, providing solutions to environmental problems [11-13]. However, the green economy has complex impacts on local development: even in case of industries which seem to take an immediate and direct advantage of green economy policies (such as tourism and agriculture), on closer analysis, a positive impact is possible only when the local economic and government bodies are involved in the change towards the green economy [14-18]. These difficulties increase when sustainability is evaluated according to a multi-dimensional approach (as in the case of the EU definition, which relies on economic, environmental, and social dimensions), as recognized in the literature [19]. In this context, although local governments and bodies play a marginal role in designing the framework of green regulation, they are crucial to manage the transition and facilitate the successful implementation of the green economy in terms of local development [20,21]. The transition to the green economy is rarely based on pure win-win solutions: in the context of the labor market, for example, the green economy poses a delicate integration problem not so much for high skilled workers, who seem to be favored by green transition [22], but rather for low skilled workers, people with disabilities, and informal workers [23-25]. Therefore, local authorities are expected to take steps to remove and prevent the negative consequences connected with the transition whilst also promoting negotiations and dialogue between local stakeholders with different priorities, which may help in achieving a balance between commercial, technological, environmental, and social interests [26-28]. The integration of green policies with local economic development strategies is a challenging task, and it requires - at the local level - a comprehensive approach (clear vision, strong leadership, industry strategy, investments in infrastructures, partnership establishment, and community engagement) in order to maximize the potential of the green economy and ensure effectiveness [29]. Greening the economy will have great impacts on many economic industries (agriculture, transport, extractive industries, manufacturing, construction, services, etc.) which are extensively present at local levels as Small and Medium-sized Enterprises (SMEs). SMEs are crucial for most national economies in the EU-28: they account for more than $99.8 \%$ of all businesses, and generate more than $56 \%$ of value added and about $66.6 \%$ of employment. Within this group of companies, Medium-sized Enterprises (MEs) form a limited number $(0.9 \%$ of all businesses), but they generate $18 \%$ of the value added and $16.8 \%$ of the employment [3]. Micro SMEs account for $93 \%$ of all enterprises, Small SMEs account for $5.9 \%$, Medium-sized account for $0.9 \%$, and Large Enterprises account for $0.2 \%$. Taking value added into consideration, Micro SMEs account for 20.8\%, Small SMEs account for $17.6 \%$, and Medium-sized $18 \%$ and Large Enterprises account for $43.6 \%$. Micro SMEs generate $29.7 \%$ of employment, Small SMEs generate $20.1 \%$, Medium-sized SMEs generate $16.8 \%$, and Large Enterprises generate 33.4\% [30]. In Italy, the shares of employment and value added generated by SMEs are particularly high (78.1\% and $66.9 \%$, respectively) compared to the EU average. MEs account for 12.5\% of employment (compared with 16.8\% in the EU-28), while the share of value-added is similar (17.9\% vs. 18\% for the EU-28) [30]. Considering the importance of SMEs for the EU-28, their contribution is vital both for the success of the green economy objectives (according to the EU definition) and for the implementation of new local development policies based on economic transformation and sustainable growth. However, SMEs often face difficulties in accessing bank finance and financial markets, and this may weaken their ability to contribute to sustainable development, unless bank and financial credit are substituted by trade credit, which is one of the main sources of finance for SMEs.

The present study therefore aims to investigate the relationships between trade credit and the orientation to green, environmentally-friendly production by Italian manufacturing firms. We focus, in particular, on MEs for four main reasons. First and foremost, there have so far been few studies on MEs and the importance of trade credit as a financial source. Second, because SMEs and MEs are particularly important in Italy: in Italy, MEs account for $18 \%$ of the total value added and $16.8 \%$ of the employment (see above), and trade 
credit in Italy is more important than in many other European countries [31]; the present work will therefore concentrate on Italian manufacturing firms. Third, because MEs are widely believed to have easier access to bank and financial credit than smaller firms, we aim to verify whether MEs using sustainable forms of production rely on trade credit to a greater or lesser degree than other firms. Fourth, because trade credit consists of accounts payable and receivable, we aim to verify whether these two accounts depend on each other, and on the respective amounts in the previous year, particularly in the case of green MEs compared with non-green MEs.

The rest of the paper is structured as follows. Section 2 presents a literature review. Section 3 describes the sample, the studied variables, their descriptive statistics, and the methodology we used in the analysis. Section 4 presents our results, and Sections 5 and 6 discuss and conclude.

\section{Literature Review}

The literature on trade credit shows that its relationship with bank credit is complex. Superficially, it may appear that trade credit is a substitute for bank credit, because it is mainly requested by companies with poor access to bank credit. The substitution of trade credit for bank credit appears to be more prevalent in contexts of monetary tightening [32-39] and during a financial crisis [40]. This theory has, however, been challenged: empirical studies [41,42] in the US have found no support for it, while other studies [43,44] demonstrate that trade credit is substituted for bank credit in the US for firms without access to open-market funds. Research suggests that supplier companies could have a competitive advantage over the banks in the exploitation of informal means that guarantee the repayment of the loan. This competitive advantage may reflect better and/or less expensive information on the financial situation of client firms [45-47], monitoring advantages [48-51], and product market imperfections [52]. The competitive advantage could be particularly big for small, young, and opaque firms [53,54], or those operating in countries with poorly-developed financial institutions [43]. While borrowers are likely to view bank and trade credit as substitutes, firms with greater access to bank credit can redistribute it to their (financially weaker) clients in the form of trade credit [40,55-62]. Trade credit can thus be viewed as being complementary to financing from financial intermediaries, who lend to suppliers who in turn relend to their clients [63]. Still on the complementarity hypothesis, certain studies [64,65] have demonstrated large differences across industries in trade credit terms but little variation within industries across time, so that trade credit can be considered as a component of a long-term portfolio management strategy [49], a tool for the consolidation of relationships with clients due to the product quality guarantee [66], for price discrimination [46,67-70], and to increase firms' profitability [71]. Trade credit has also been considered as a useful instrument for the provision of liquidity to the economy by limiting the default costs of buying companies [72]. Other studies demonstrate that firms facing variable demand make more use of trade credit than companies that have stable demand [68]. A growing body of literature shows how the presence of a robust local financial system has positive effects on the development of a network of SMEs $[73,74]$. The development of local banks stimulates product innovation, stimulates investments in research and development [75], reduces financial constraints [76], and eventually increases the use of debt [77]. Furthermore, the structure of local banking systems affects the availability of credit $[46,78]$. The substitution/complementarity relationship between trade and banking credit has been analyzed more specifically with particular reference to the level of the local banking system development. The findings vary: in Europe, the substitution theory seems to be demonstrated [79], while in Italy [80], a positive correlation between local bank development and the provision of trade credit has been confirmed. Trade credit can be used both to finance purchases (accounts payable) and clients (accounts receivable), such that other studies [81] investigated the impact of transaction costs and operational conditions on trade credit. Studies investigating the relationship between accounts payable and receivable concluded that the matching hypothesis (trade debt is influenced by the 
trade credit policy) is verified [82,83]. Other empirical research on European SMEs [59] demonstrated the existence of a substantial match between the maturity of short-term assets and liabilities, although accounts payable appeared to be positively correlated, and accounts receivable negatively correlated, with sales growth. Empirical research on UK firms [84] found a strong positive correlation between inventory/total assets, accounts receivable/total assets, and accounts payable/total assets. A more recent analysis on Italian SMEs [85] in the period 2005-2012 concluded that, although there is evidence of a substitution effect between trade and bank credit, the accounts payable in one year depend on those of the previous year, and that the accounts receivable are positively related to accounts payable. In other words, operational conditions, transaction costs, and firms' business environments influence the demand and supply of trade credit [86]. This may be because the transactional component, which characterizes trade credit in addition to the financial component, and which facilitates the exchange of goods, accounts for the time invariant aspects of trade credit within industries and a high heterogeneity across industries, particularly in cases of monetary tightening $[87,88]$. Some studies examined the relationship between trade credit and company growth, and found that where there is an absence [70] or shortage [89] of bank loans for a given liquidity requirement, an increase in production will require an increase of trade credit. Other studies [43] found that industries which use more trade credit grow faster in countries with poorly developed financial systems, and that companies facing a liquidity shortage try to overcome the problem by taking more trade credit [90]. An analysis [91] on 600,000 firms (mainly SMEs) in eight Euro-area countries, with some heterogeneity in their financial systems, in the period 1993-2008, verified that firm growth depends on trade credit. Although the analysis demonstrated that Euro-area firms use trade credit to finance growth, in countries where the supply of bank loans or debt securities is larger, the sensitivity of firm growth to trade credit tends to be smaller. Moreover, focusing on the firms themselves, trade credit seems to be particularly important for firms which are more vulnerable to financial market imperfections, such as young or small firms. For three main reasons, the present study is based on the assumption that the sum of accounts payable and accounts receivable impacts heavily on firm performance. First, because firms can manage both their accounts payable and accounts receivable to optimize performance. Second, because both types of trade credit are an indication of how much of the firm's operations are shielded from developments in the financial system. Third, because there is an interaction between the financial market and trade credit. Firms may have a contract with a financial intermediary to finance a portion of their accounts receivable so that the firm's account receivables do not affect the firm's working capital. In this way, the financial intermediary indirectly finances the firm's customers, while the firm pays the monitoring costs and default risk. The importance of trade credit in the different stages of the business life cycle of SMEs has been analyzed, assuming the existence of a linear or non-linear relationship between firm-age, as a proxy of the life cycle firm stage and trade credit. A linear relationship implies a positive or negative relationship between the size of the trade credit and the firm's age. A linear approach implies a single sign (positive or negative) explaining the importance of trade credit throughout the life of the firm. A positive relationship might imply that older firms have maintained lasting relationships with their suppliers [92], and thus have easier access to trade credit than younger companies [46]. In turn, suppliers could be interested in consolidating business relations with their clients whilst maintaining their own business and future sales $[93,94]$. A negative relationship, on the other hand, could be explained by asymmetric information financial theory [95] or the pecking order theory [96]. In asymmetric information financial theory, a firm's age is considered a proxy of the firm's financial transparency $[97,98]$ and reputation [99]. A negative relationship implies that trade credit is more important for younger than older firms, because younger firms have not yet acquired a sufficient level of reputation, credit worthiness, or transparency [100-102]. According to the pecking order theory, firms prefer to use retained earnings, followed by debt (from the cheapest to most expensive), and finally equity. This implies that younger firms may lack the capacity 
to generate enough earnings and therefore use more trade credit [103] than older firms, which have a greater capacity to generate internal resources and better access to financial debt [104]. Non-linear relationship occurs when trade credit varies over the life cycle [105].

Empirical analysis has produced non-conclusive results. Studies finding a negative linear relation have been carried out in the UK [92,100], Finland [106], emerging countries [107], Japan [102], Italy [80], Portugal-Spain [108], and Spain [103]. Studies finding a positive linear relation have been carried out in the USA [94], Japan [109], and the EU [93]. Lastly, two other studies found no relationship between trade credit and firm age: the first on Swedish firms [110], and the second on EU firms [111]. Other studies finding evidence of non-linear relationship have been carried out in the USA [46,112] and the EU [59,105,113].

The relationship between firm age and trade credit depends on the sector, which is extremely important in the financial decisions of SMEs [114]. The use of trade credit varies significantly across industries, but the variations are small within each industry $[115,116]$. A recent analysis [117] focusing on manufacturing SMEs operating in 12 EU countries in the period 2008-2014 demonstrated both a negative and a significant non-linear relationship between firm age and trade credit. As such, although younger firms rely more heavily on trade credit, it also plays a key role for older firms, which may reflect a preference towards older SMEs due a relationship of trust built up by suppliers over the years. The impact of trade credit on a variable representing the 'sustainable growth of the firm' (longterm profitability and lasting competitiveness without exhausting the firm's financial resources) has been investigated recently [118] on a sample of Chinese A-share private listed companies from 2003 to 2017. The findings were that trade credit plays an important role in accelerating the search for sustainable growth, particularly for firms with a higher level of internal control quality, and that in areas with a lower (higher) financial competition, the contribution of trade credit to the sustainable growth of the firm is stronger (weaker). This confirmed previous findings $[43,91]$.

As such, previous studies agree overall that SMEs have less access to bank credit and financial markets. Because of the insufficient regulation, knowledge, and implementation of sustainability criteria by SMEs, this limitation could be more serious in the case of new types of sustainable green and environmental production. Trade credit for SMEs could, in fact, play a major role in supplying finance for new types of production, and could be a tool for the consolidation of relationships with clients. Trade credit could play an important role in product quality guarantees, which are particularly important for innovative products.

The following research questions were formulated:

1. Do green Italian manufacturing MEs rely more heavily on trade credit than bank and financial credit compared to other MEs?

2. Are green and ecological Italian manufacturing MEs characterized by a different importance of payable and receivable accounts? Do payable and receivable accounts depend on each other?

3. Is there a relationship between the importance of payable and receivable trade credit and the size/age of the firm, distinguishing between green and non-green firms?

\section{Materials and Methods}

\subsection{Sample and Data}

The main sources of data were the AIDA (Analisi Informatizzata Delle Aziende italiane) Bureau Van Dijk database, containing all of the financial and governance data of Italian SMEs, and ISTAT (Istituto Nazionale di Statistica), the Italian National Institute of Statistics, a public research organisation, which is the main producer of official statistics in the service of citizens and policy-makers.

Our sample includes enterprises belonging to "industry in the strict sense": a commonly used expression by ISTAT (see, for example, the ISTAT Annual report 2020 [119]). It refers to manufacturing sectors, excluding construction. In the Classification of Economic Activity used by ISTAT (ATECO 2007 code) 'industry in the strict sense' corresponds to Sections B-E. Section B is 'Extraction of minerals from quarries and mines', Section C is 
'Manufacturing activities', and Sections D and E refer to 'Supply of electricity, gas, steam and air conditioning' and 'Supply of water: sewer networks, activities of waste management and remediation'. All of the firms in our sample belong to 'industry in the strict sense', and are Medium Enterprises (MEs). According to the European Commission (EC) definition, an ME has between 50 and 250 employees, between a 10 million and 50 million euro annual turnover, and from a 10 million to a 43 million euro balance sheet total. The final sample included 10,125 Italian MEs.

We carried out a panel analysis with 101,250 observations, of which 3920 refer to firms belonging to the 'green' sector, during the period 2010-2019. The concept of the 'green economy' [120] is perceived as a pathway to sustainability by international organizations such as The World Bank [121], the United Nations Environment Programme [7], and the European Commission [9]. The green economy focuses on resource efficiency and natural capital as the pillars of the economy. An inclusive green economy is associated with economic growth, human development, and opportunities for people (to improve the living environments and jobs) and for businesses (to increase benefits through more efficient production practices that generate savings). A study by the Politecnico di Milano and Camera di Commercio di Milano [122] identified specific 'green' sectors on the basis of these concepts. Consistently with the mentioned study, here, we selected green sectors among those in 'industry in the strict sense' using the following ATECO 2007 codes (see also [122]):

- $\quad$ Collection, reuse, recycling of waste: codes 38.11.00, 38.12.00, 38.21.01, 38.21.09, 38.22.00, 38.31.10, 38.32.10, 38.32.20, 38.32.30 e 39.00.01;

- Efficiency of water systems: code 36.00.00;

- Planning, reclamation and rehabilitation of the territory: code 30.00.09;

- Waste water treatment: code 37.00.00;

- $\quad$ Energy storage: code 27.20.00.

Most of the companies included in the sample were old companies. Consistently with the previous literature [123-125], we classified as young firms those up to 5 years old, as mature firms those from 6 to 10 years old, and as old firms those over 10 years old. Panels A and B of Table 1 present the sample distribution by the type of sector (i.e., green or non-green) and age, respectively.

Table 1. Observations by the type of sector and firm age.

\begin{tabular}{ccc}
\hline Panel A: Observations by type of firm sector & \\
\hline Type of Sector & No. of Observations & \% of Total \\
\hline Green & 3920 & 3.87 \\
Non-green & 97,330 & 96.13 \\
Total & 101,250 & 100 \\
\hline Panel B: Observations by firm age & & \\
\hline Age & No. of bservations & \% of Total \\
\hline Young & 4080 & 4.03 \\
Mature & 7120 & 7.03 \\
Old & 90,050 & 88.94 \\
Total & 101,250 & 100 \\
\hline
\end{tabular}

\subsection{Variables and Descriptive Statistics}

In line with previous literature e.g., $[46,59,117,126,127]$, the dependent variable is 'Trade credit', defined as the ratio of trade payable to total assets. We observed the use of trade credit during the firm's life cycle by considering, among the independent variables, 'Age', which is the number of years of a firm's activity. In particular, the logarithm of (1+ age) was used. The regression was also tested using dummy variables related to firm age, and the results did not change. Following previous studies, we also considered a set of control variables, including firm 'Size' (i.e., the logarithm of the total assets); 'Profitability', 
which is the ratio of earnings before interest, taxes, depreciation and amortization (EBITDA) to total assets; 'Liquidity' (i.e., the ratio of operating cash flow to total assets); trade credit in the previous year ('Trade credit $t_{t-1}$ '), which is the ratio of trade payable to the total assets of the previous year; and 'Accounts receivable' (i.e., the ratio of trade receivable to total assets). In order to verify whether a potential substitution effect between trade and bank credit exists, we considered 'Short-term bank credit' and 'Long-term bank credit', measured as the ratio of short-term debts to total assets and the ratio of long-term debts to total assets, respectively. We also studied the potential link between local development and trade credit. We thus included the following variables observed at the regional level: Gross Domestic Product ('GDP') (i.e., the logarithm of the GDP), 'Employment rate' (i.e., the ratio between the number of people employed and the population aged 15 or over), and educational level (i.e., a dummy variable - 'low educational level' or 'high educational level'-referring to the educational qualification of the population). Finally, we considered the surface area (the logarithm) of the region of Italy where the headquarters of each firm is located. Table 2 shows the descriptive statistics for these variables.

Table 2. Descriptive statistics.

\begin{tabular}{|c|c|c|c|c|c|}
\hline Variables & Mean & Median & Std.Dev. & Min. & Max \\
\hline Trade credit & 0.237 & 0.208 & 0.215 & 0.000 & 0.998 \\
\hline Age & 31.413 & 31.000 & 17.455 & 0.000 & 146.000 \\
\hline Size & 9.803 & 9.802 & 0.939 & 1.927 & 15.517 \\
\hline Profitability & 0.079 & 0.075 & 0.112 & -1.772 & 0.988 \\
\hline Liquidity & 0.053 & 0.055 & 0.161 & -7.552 & 5.917 \\
\hline Trade credit $t_{t-1}$ & 0.239 & 0.210 & 0.213 & 0.000 & 0.975 \\
\hline Account receivable & 0.253 & 0.245 & 0.183 & 0.000 & 0.958 \\
\hline Short-term bank credit & 0.126 & 0.085 & 0.134 & 0.000 & 0.999 \\
\hline Long-term bank credit & 0.074 & 0.040 & 0.096 & 0.000 & 0.988 \\
\hline GDP & $193,733.661$ & $148,227.200$ & $122,949.810$ & 4625.600 & $390,461.000$ \\
\hline Employment rate & 0.633 & 0.649 & 0.067 & 0.389 & 0.713 \\
\hline Area & $20,177.451$ & $22,444.542$ & 5285.339 & 3260.855 & $25,832.545$ \\
\hline
\end{tabular}

Table 3 presents the correlations between all of the variables used in the analysis. We also ran a test of variance inflation factors: VIFs (Table 4). No explanatory variables show VIF values above 10; thus, multicollinearity is not a concern in our models [128].

Table 3. Correlation coefficient matrix.

\begin{tabular}{|c|c|c|c|c|c|c|c|c|c|c|c|c|}
\hline Variables & $\begin{array}{l}\text { Trade } \\
\text { Credit }\end{array}$ & Age & Size & Profitability & Liquidity & $\begin{array}{c}\text { Trade } \\
\text { Credit }_{t-1}\end{array}$ & $\begin{array}{c}\text { Account } \\
\text { Receiv- } \\
\text { able }\end{array}$ & $\begin{array}{l}\text { Short- } \\
\text { Term } \\
\text { Bank } \\
\text { Credit }\end{array}$ & $\begin{array}{l}\text { Long- } \\
\text { Term } \\
\text { Bank } \\
\text { Credit }\end{array}$ & GDP & $\underset{\text { Rate }}{\text { Employment }}$ & Area \\
\hline Trade credit & 1.000 & & & & & & & & & & & \\
\hline Age & -0.131 * & 1.000 & & & & & & & & & & \\
\hline Size & -0.278 * & 0.142 * & 1.000 & & & & & & & & & \\
\hline Profitability & $-0.147^{*}$ & -0.031 * & 0.005 * & 1.000 & & & & & & & & \\
\hline Liquidity & -0.064 * & -0.001 & 0.026 * & $0.208^{*}$ & 1.000 & & & & & & & \\
\hline $\begin{array}{c}\text { Trade } \\
\text { credit }_{t-1}\end{array}$ & $0.789 *$ & -0.152 * & -0.296 * & -0.051 * & 0.028 * & 1.000 & & & & & & \\
\hline $\begin{array}{c}\text { Account } \\
\text { receivable }\end{array}$ & $0.277^{*}$ & -0.093 * & -0.256 * & $0.079 *$ & 0.013 & $0.299 *$ & 1.000 & & & & & \\
\hline $\begin{array}{l}\text { Short-term } \\
\text { bank credit }\end{array}$ & $-0.115^{*}$ & -0.009 & -0.061 * & -0.091 * & $-0.007^{*}$ & 0.099 * & -0.039 * & 1.000 & & & & \\
\hline $\begin{array}{l}\text { Long-term } \\
\text { bank credit }\end{array}$ & $0.019 *$ & 0.002 & -0.023 * & -0.024 * & -0.001 & 0.011 * & $-0.005^{*}$ & $0.092 *$ & 1.000 & & & \\
\hline GDP & -0.037 * & $0.093 *$ & $0.024 *$ & $0.016^{*}$ & $0.012 *$ & -0.035 * & -0.032 * & $-0.016^{*}$ & $-0.012 *$ & 1.000 & & \\
\hline $\begin{array}{l}\text { Employment } \\
\text { rate }\end{array}$ & -0.043 * & $0.083 *$ & $0.017^{*}$ & 0.031 * & 0.012 * & $-0.048^{*}$ & -0.077 * & -0.022 * & -0.001 & 0.349 * & 1.000 & \\
\hline Area & -0.031 * & 0.090 * & 0.014 * & 0.020 * & 0.018 * & -0.031 * & -0.012 & $-0.019 *$ & -0.009 * & $0.625 *$ & 0.288 * & 1.000 \\
\hline
\end{tabular}

Notes: ${ }^{*}$ indicates significance at the $5 \%$ level. 
Table 4. VIF test.

\begin{tabular}{ccc}
\hline Variable & VIF & 1/VIF \\
\hline Employment rate & 6.33 & 0.158 \\
GDP & 2.78 & 0.360 \\
Area & 1.73 & 0.579 \\
Trade credit $t_{-1}$ & 1.20 & 0.834 \\
Account receivable & 1.16 & 0.870 \\
Size & 1.15 & 0.870 \\
Profitability & 1.07 & 0.934 \\
Age & 1.05 & 0.952 \\
Liquidity & 1.05 & 0.953 \\
Short-term bank credit & 1.03 & 0.968 \\
Long-term bank credit & 1.01 & 0.991 \\
\hline
\end{tabular}

\subsection{Methodology}

We followed a panel data approach in order to answer our research questions. The equation model included the variables described in Section 3.2, and additional time dummies as control variables:

Trade credit it $=\beta_{0}+\beta_{1}$ Age $+\beta_{2}$ Size $+\beta_{3}$ Profitability $+\beta_{4}$ Liquidity

$+\beta_{5}$ Trade credit $_{t-1}+\beta_{6}$ Account receivable $+\beta_{7}$ Short-term bank credit

$+\beta_{8}$ Long-term bank credit $+\beta_{9} \mathrm{GDP}+\beta_{10}$ Employement rate $+\beta_{11}$ Area

$+\beta_{12}$ Educational level dummies + Year dummies $+\mu_{\mathrm{it}}+\varepsilon_{\mathrm{it}}$

where $i$ is the firm, and $t$ is the time period, $\mu_{\mathrm{i}}$ represents the firm-specific effects, and $\varepsilon_{\mathrm{it}}$ represents the measurement errors.

Equation (1) was estimated using estimators of fixed and random effects in order to take the individual effects into account $\left(\mu_{\mathrm{i}}\right)$, with clustered standard errors at the firm level. The Hausman test was performed in order to ascertain whether the individual effects are fixed or random. If the null hypothesis is rejected, a correlation between the independent variables and the individual unobservable effects does not exist, and the random effects model is considered a good estimator. We used the Hausman test to differentiate between a fixed effects model and a random effects model. The Hausman statistic was calculated from the following formula:

$$
H=(\beta R E-\beta F E)^{\prime} \operatorname{Var} \beta R E-\operatorname{Var} \boldsymbol{\beta} F E-1(\boldsymbol{\beta} R E-\boldsymbol{\beta} F E),
$$

where $\beta R E$ and $\beta F E$ are the vectors of the coefficient estimates for the random and fixed effect models, respectively. This statistic is $\chi 2(k)$ distributed under the null hypothesis. The degrees of freedom $k$ equal the number of factors. The Hausman test results (13.11, $p>0.05$ ) suggest that random effect models are appropriate for our dataset. The tables below, therefore, show only the results of the estimation with a random effect model.

\section{Results}

Table 5 reports the first results of the analysis. Model 1 includes only the following control variables: age, size, profitability, liquidity, trade credit in the previous year, and accounts receivable. Model 2 adds short-term and long-term bank credit into the equation in order to assess the potential replacement effect of trade credit over bank debt. Model 3 adds GDP, employment rate, educational levels and the area of the region where the headquarters of each ME is located. 
Table 5. Results of the analysis: overall sample.

\begin{tabular}{|c|c|c|c|}
\hline Variables & Model 1 & Model 2 & Model 3 \\
\hline Constant & $\begin{array}{l}0.259 * * * \\
(0.000)\end{array}$ & $\begin{array}{l}0.189 * * * \\
(0.000)\end{array}$ & $\begin{array}{l}0.199 * * * \\
(0.000)\end{array}$ \\
\hline Age & $\begin{array}{l}-0.008^{* * *} \\
(0.000)\end{array}$ & $\begin{array}{l}-0.006^{* * *} \\
(0.000)\end{array}$ & $\begin{array}{c}-0.006^{* * *} \\
(0.000)\end{array}$ \\
\hline Size & $\begin{array}{l}-0.017^{* * *} \\
(0.000)\end{array}$ & $\begin{array}{c}-0.013^{* * *} \\
(0.000)\end{array}$ & $\begin{array}{c}-0.012 * * * \\
(0.000)\end{array}$ \\
\hline Profitability & $\begin{array}{c}-0.190^{* * *} \\
(0.000)\end{array}$ & $\begin{array}{c}-0.177^{* * *} \\
(0.000)\end{array}$ & $\begin{array}{c}-0.178^{* * *} \\
(0.000)\end{array}$ \\
\hline Liquidity & $\begin{array}{l}-0.020^{* * *} \\
(0.000)\end{array}$ & $\begin{array}{l}-0.023^{* * *} \\
(0.000)\end{array}$ & $\begin{array}{c}-0.0243^{* * *} \\
(0.000)\end{array}$ \\
\hline Trade credi $_{t-1}$ & $\begin{array}{l}0.691^{* * *} \\
(0.000)\end{array}$ & $\begin{array}{l}0.727^{* * *} \\
(0.000)\end{array}$ & $\begin{array}{l}0.735^{* * * *} \\
(0.000)\end{array}$ \\
\hline Account receivable & $\begin{array}{l}0.091^{* * *} \\
(0.000)\end{array}$ & $\begin{array}{l}0.102 * * * \\
(0.000)\end{array}$ & $\begin{array}{l}0.099 * * * \\
(0.000)\end{array}$ \\
\hline Short-term bank credit & & $\begin{array}{c}-0.0246^{* * *} \\
(0.000)\end{array}$ & $\begin{array}{c}-0.025^{* * *} \\
(0.000)\end{array}$ \\
\hline Long-term bank credit & & $\begin{array}{c}0.004 \\
(0.314)\end{array}$ & $\begin{array}{c}0.004 \\
(0.375)\end{array}$ \\
\hline GDP & & & $\begin{array}{c}-1.12 \times 10^{-7 * * *} \\
(0.000)\end{array}$ \\
\hline Employment rate & & & $\begin{array}{c}-0.040^{* *} \\
(0.041)\end{array}$ \\
\hline Area & & & $\begin{array}{c}-2.40 \times 10^{-7} \\
(0.145)\end{array}$ \\
\hline High educational level & & & $\begin{array}{c}0.098 \\
(0.133)\end{array}$ \\
\hline Year dummies & included & included & Included \\
\hline Wald $\chi^{2}$ & $67,607.10^{* * *}$ & $67,439.61^{* * *}$ & $63,492.81^{* * *}$ \\
\hline R squared & 0.500 & 0.650 & 0.645 \\
\hline
\end{tabular}

The results show a negative relationship between age and trade credit, and this effect is statistically significant at the $1 \%$ level in all three models. Younger firms, probably because of difficulty accessing bank credit, tend to use more trade credit. This negative effect may be strengthened by the early formation of the manufacturer-supplier relationship. Figure 1 illustrates trade credit as a function of age in our sample. The linear approximation clearly shows that the relationship is negative. Figure 1 shows that, in the mature stages of the life cycle of MEs, the sign of the relationship between trade credit and age ceases to be negative, and trade credit still plays a central role, but to a slightly lesser extent than in the earlier stages. Suppliers grant trade credit to older SMEs easily due to a relationship of trust built up over the years.

Size, profitability, and liquidity present a negative relation with trade credit, which shows that smaller MEs, and MEs with lower EBITDA and operational cash flows use more supplier financing.

In Models 2 and 3, the results indicate that firms use more trade credit when they have difficulties in accessing short-term debt, showing that trade credit and bank credit are potentially substitute financing resources. GDP and employment rate present a negative relationship with trade credit, showing that a relationship between local development and trade credit exists. Finally, we found a positive relationship between trade credit in the previous year, and accounts receivable and trade credit. Accounts payable and accounts receivable thus appear to depend on each other. We therefore investigated the determinants of accounts receivable. Table 6 shows that younger and smaller MEs grant less credit to their customers. On the other hand, MEs with higher EBITDA and operational cash flows grant more client credit. 


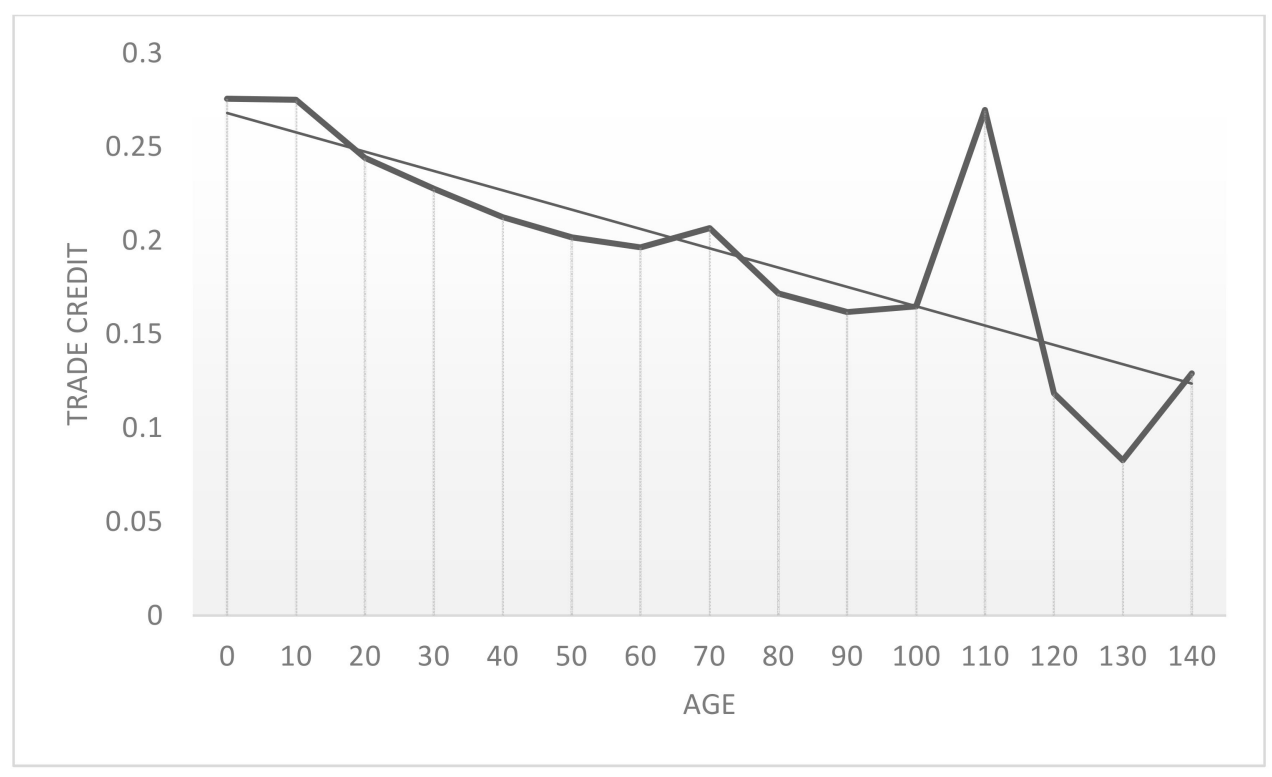

Figure 1. The relationship between firm age and trade credit: overall sample.

Table 6. Determinants of account receivable: overall sample.

\begin{tabular}{cc}
\hline Variables & \\
\hline Constant & $\left(0.321^{* * *}\right.$ \\
& $-0.0008^{* * *}$ \\
Age & $(0.000)$ \\
& $-0.002^{*}$ \\
Pize & $(0.007)$ \\
Profitability & $0.090^{* * *}$ \\
Liquidity & $(0.000)$ \\
Year dummies & $0.002^{*}$ \\
Wald $\chi^{2}$ & $(0.006)$ \\
R squared & included \\
\hline
\end{tabular}

Notes: ${ }^{*} p$-value $<0.1,{ }^{* *} p$-value $<0.05,{ }^{* * *} p$-value $<0.01$. The robust standard errors are in parentheses.

The present work aimed to investigate the existence of a significant relationship between trade credit and green Italian medium-sized enterprises (MEs). In order to delve into the relationship between green MEs and trade credit compared to other MEs, we carried out an analysis considering green and non-green MEs separately. First, Table 7 presents the descriptive statistics for green and non-green MEs, and the significant differences according to a $t$-test. The unpaired $t$ method tested the null hypothesis that the population means related to two independent samples from an approximately normal distribution are equal. Assuming equal variances, the test statistic is calculated as:

$$
t=\frac{\bar{x}_{1}-\bar{x}_{2}}{\sqrt{s^{2}\left(\frac{1}{n 1}+\frac{1}{n 1}\right)}}
$$

where $x$ bar 1 and $x$ bar 2 are the sample means, $s^{2}$ is the pooled sample variance, $n_{1}$ and $n_{2}$ are the sample sizes, and $t$ is a Student $t$ quantile with $n_{1}+n_{2}-2$ degrees of freedom.

Tables 8 and 9 show the results of the three models applied to the sub-samples of green and non-green firms, respectively. 
Table 7. Descriptive statistics for the green and non-green MEs.

\begin{tabular}{cccccc}
\hline & \multicolumn{2}{c}{ Green MEs } & \multicolumn{2}{c}{ Non-Green MEs } \\
\hline Variables & Mean & Std.Dev. & Mean & Std.Dev. & $t$-Test \\
\hline Trade credit & 0.241 & 0.183 & 0.235 & 0.215 & $1.660^{*}$ \\
Age & 23.112 & 13.610 & 31.414 & 17.458 & $-29.416^{* * *}$ \\
Size & 9.993 & 1.300 & 9.803 & 0.934 & $11.319^{* * *}$ \\
Profitability & 0.080 & 0.089 & 0.080 & 0.112 & 0.202 \\
Liquidity & 0.025 & 1.856 & 0.561 & 0.345 & $-3.596^{* * *}$ \\
Trade credit $t$-1 & 0.246 & 0.183 & 0.239 & 0.214 & $1.789^{*}$ \\
Account receivable & 0.302 & 0.244 & 0.251 & 0.180 & $17.088^{* * *}$ \\
Short-term bank credit & 0.152 & 0.235 & 0.136 & 0.246 & $3.591^{* * *}$ \\
Long-term bank credit & 0.074 & 0.094 & 0.077 & 0.150 & -1.122 \\
GDP & $145,599.8$ & $108,989.4$ & $193,765.1$ & $122,953.2$ & $-22.908^{* * *}$ \\
Employment rate & 0.580 & 0.102 & 0.633 & 0.067 & $-47.669^{* * *}$ \\
Area & $18,779.67$ & 6079.32 & $20,178.15$ & 5284.98 & $-16.148^{* * *}$ \\
\hline
\end{tabular}

Notes: ${ }^{*} p$-value $<0.1 ; * *$-value $<0.05 ;{ }^{* * *} p$-value $<0.01$

Table 8. Results of the analysis: green MEs.

\begin{tabular}{|c|c|c|c|}
\hline Variables & Model 1 & Model 2 & Model 3 \\
\hline Constant & $\begin{array}{l}0.066^{* *} \\
(0.005)\end{array}$ & $\begin{array}{l}0.069^{* *} \\
(0.005)\end{array}$ & $\begin{array}{c}0.007 \\
(0.850)\end{array}$ \\
\hline Age & $\begin{array}{l}-0.002 \\
(0.574)\end{array}$ & $\begin{array}{l}-0.001 \\
(0.958)\end{array}$ & $\begin{array}{c}0.001 \\
(0.744)\end{array}$ \\
\hline Size & $\begin{array}{l}-0.003 \\
(0.113)\end{array}$ & $\begin{array}{l}-0.003 \\
(0.108)\end{array}$ & $\begin{array}{l}-0.002 \\
(0.368)\end{array}$ \\
\hline Profitability & $\begin{array}{c}-0.207^{* * * *} \\
(0.000)\end{array}$ & $\begin{array}{c}-0.222^{* * *} \\
(0.000)\end{array}$ & $\begin{array}{c}-0.215^{* * *} \\
(0.000)\end{array}$ \\
\hline Liquidity & $\begin{array}{c}-0.004^{* * * *} \\
(0.000)\end{array}$ & $\begin{array}{c}-0.004^{* * *} \\
(0.000)\end{array}$ & $\begin{array}{c}-0.004^{* * * *} \\
(0.000)\end{array}$ \\
\hline Trade credi $_{t-1}$ & $\begin{array}{c}0.702^{* * * *} \\
(0.000)\end{array}$ & $\begin{array}{c}0.691^{* * * *} \\
(0.000)\end{array}$ & $\begin{array}{l}0.707^{* * *} \\
(0.000)\end{array}$ \\
\hline Account receivable & $\begin{array}{l}0.156^{* * *} \\
(0.000)\end{array}$ & $\begin{array}{c}0.158^{* * *} \\
(0.000)\end{array}$ & $\begin{array}{c}0.159^{* * * *} \\
(0.000)\end{array}$ \\
\hline Short-term bank credit & & $\begin{array}{c}-0.041^{* * *} \\
(0.000)\end{array}$ & $\begin{array}{c}-0.040^{* * *} \\
(0.000)\end{array}$ \\
\hline Long-term bank credit & & $\begin{array}{c}0.005 \\
(0.814)\end{array}$ & $\begin{array}{c}0.006 \\
(0.788)\end{array}$ \\
\hline GDP & & & $\begin{array}{c}2.00 \times 10^{-7} \\
(0.116)\end{array}$ \\
\hline Employment rate & & & $\begin{array}{l}0.120 \text { * } \\
(0.089)\end{array}$ \\
\hline Area & & & $\begin{array}{c}-4.54 \times 10^{-7} \\
(0.365)\end{array}$ \\
\hline High educational level & & & $\begin{array}{l}-0.176 \\
(0.485)\end{array}$ \\
\hline Year dummies & included & included & Included \\
\hline Wald $\chi^{2}$ & $5798.52 * * *$ & $4779.90 * * *$ & 4835.27 \\
\hline $\mathrm{R}$ squared & 0.782 & 0.767 & 0.765 \\
\hline
\end{tabular}

Notes: ${ }^{*} p$-value $<0.1 ;{ }^{* *} p$-value $<0.05 ;{ }^{* * *} p$-value $<0.01$. The robust standard errors are shown in brackets.

We found that both the green and non-green MEs sub-samples show a negative relationship between profitability and liquidity and trade credit. In Models 2 and 3, the results indicate that green Italian manufacturing MEs rely on trade credit more heavily than on bank and financial credit compared to other MEs. The coefficient of short-term bank credit is, in fact, higher in the case of green companies. This is an important result because it implies that trade debt supports sustainable development. 
We found a positive relationship between trade credit $_{t-1}$ and accounts receivable, and trade credit for green and non-green companies, but the coefficients of the variables show that green Italian manufacturing MEs are characterized by the higher importance of payable and receivable accounts. Age and size present a significant negative relationship with trade credit only for non-green MEs. Figure 2 shows the relationship of trade credit as a function of age in our two sub-samples, and the higher level of trade credit for green companies.

Table 9. Results of the analysis: non-green MEs.

\begin{tabular}{|c|c|c|c|}
\hline Variables & Model 1 & Model 2 & Model 3 \\
\hline Constant & $\begin{array}{l}0.270 * * * \\
(0.000)\end{array}$ & $\begin{array}{c}0.185^{* * *} \\
(0.000)\end{array}$ & $\begin{array}{l}0.181^{* * *} \\
(0.000)\end{array}$ \\
\hline Age & $\begin{array}{c}-0.008^{* * *} \\
(0.000)\end{array}$ & $\begin{array}{c}-0.005^{* * *} \\
(0.000)\end{array}$ & $\begin{array}{c}-0.005^{* * *} \\
(0.000)\end{array}$ \\
\hline Size & $\begin{array}{c}-0.018^{* * *} \\
(0.000)\end{array}$ & $\begin{array}{c}-0.013^{* * *} \\
(0.000)\end{array}$ & $\begin{array}{c}-0.011^{* * *} \\
(0.000)\end{array}$ \\
\hline Profitability & $\begin{array}{c}-0.156^{* * *} \\
(0.000)\end{array}$ & $\begin{array}{c}-0.103^{* * *} \\
(0.000)\end{array}$ & $\begin{array}{c}-0.055^{* * *} \\
(0.000)\end{array}$ \\
\hline Liquidity & $\begin{array}{c}-0.055^{* * *} \\
(0.000)\end{array}$ & $\begin{array}{c}-0.098^{* * *} \\
(0.000)\end{array}$ & $\begin{array}{c}-0.149 * * * \\
(0.000)\end{array}$ \\
\hline Trade credi $_{t-1}$ & $\begin{array}{l}0.694^{* * * *} \\
(0.000)\end{array}$ & $\begin{array}{c}0.755^{* * *} \\
(0.000)\end{array}$ & $\begin{array}{c}0.776^{* * *} \\
(0.000)\end{array}$ \\
\hline Account receivable & $\begin{array}{l}0.084^{* * *} \\
(0.000)\end{array}$ & $\begin{array}{c}0.086^{* * *} \\
(0.000)\end{array}$ & $\begin{array}{c}0.080^{* * *} \\
(0.000)\end{array}$ \\
\hline Short-term bank credit & & $\begin{array}{c}-0.026^{* * *} \\
(0.000)\end{array}$ & $\begin{array}{c}-0.026 \text { *** } \\
(0.000)\end{array}$ \\
\hline Long-term bank credit & & $\begin{array}{c}0.003 \\
(0.340)\end{array}$ & $\begin{array}{c}0.004 \\
(0.344)\end{array}$ \\
\hline GDP & & & $\begin{array}{c}-1.12 \times 10^{-7} * * * \\
(0.000)\end{array}$ \\
\hline Employment rate & & & $\begin{array}{c}-0.037 * \\
(0.057)\end{array}$ \\
\hline Area & & & $\begin{array}{c}-2.51 \times 10^{-7} \\
(0.117)\end{array}$ \\
\hline High educational level & & & $\begin{array}{c}0.073 \\
(0.249)\end{array}$ \\
\hline Year dummies & included & included & Included \\
\hline Wald $\chi^{2}$ & $64,780.23^{* * *}$ & $71,033.54$ *** & $69,544.03^{* * *}$ \\
\hline R squared & 0.493 & 0.658 & 0.660 \\
\hline
\end{tabular}

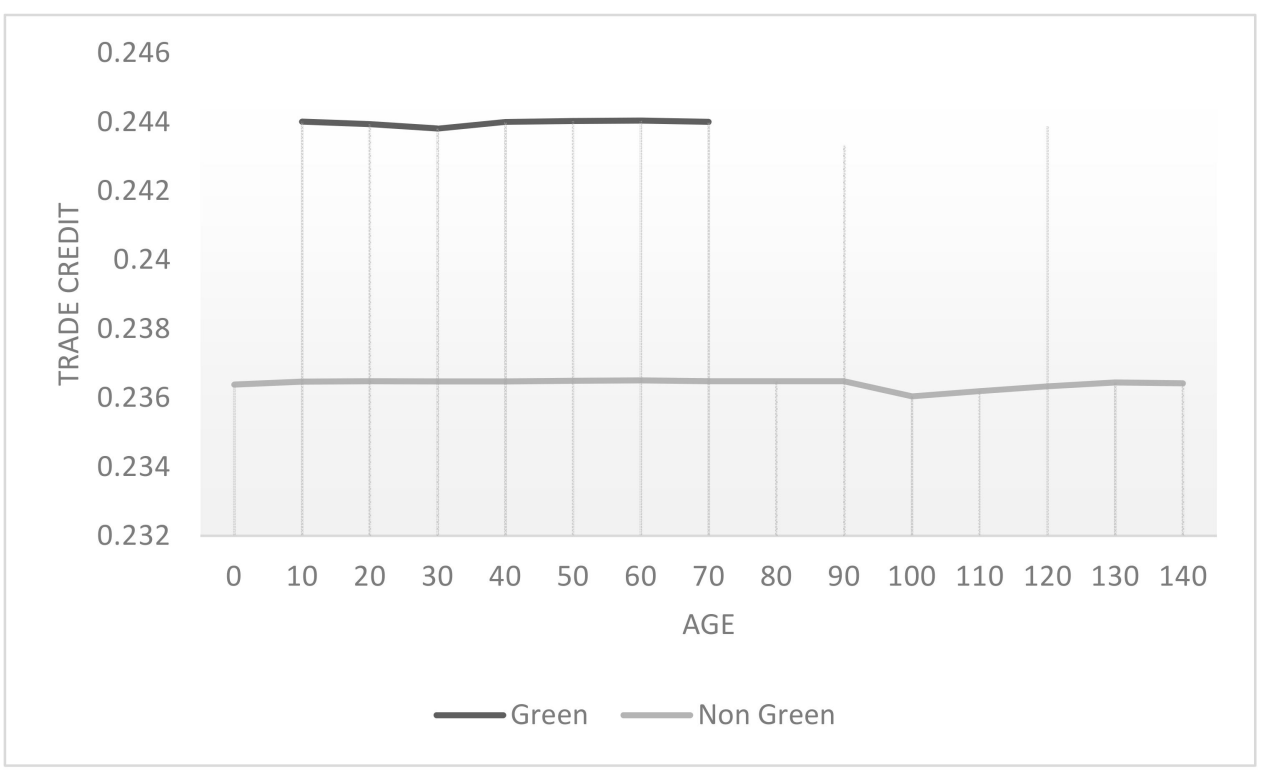

Figure 2. The relationship between firm age and trade credit: green and non-green firms. 


\section{Discussion}

This paper examined the propensity of green MEs compared to non-green MEs towards trade credit compared to bank credit. Because of their dimensions, MEs are supposed to have more access to financial and bank credit than smaller firms, such that the difference between green and non-green MEs could be assumed to be of little relevance. In addition, according to the complementary hypothesis [63], MEs could borrow from financial intermediaries and lend to their clients through trade credit. In this case, the matching hypothesis should be rejected, because the amount of accounts payable should be much lower than the amount corresponding to the accounts receivable.

In order to avoid misleading results based on the heterogeneity of companies, in terms of the variability of trade credit in different company life stages, it focuses on manufacturing companies.

The results show that green and non-green Italian manufacturing MEs rely considerably on trade credit. Size, profitability, and liquidity conditions matter: trade credit tends to be more important for smaller, less profitable, and less liquid MEs. These results are consistent with the previous results reported for SMEs. MEs, in fact, use trade credit to finance their growth $[89,101]$, and when high liquidity is available, they resort to trade credit less often [40].

Moreover, our results demonstrate that MEs tend to rely on trade credit when bank credit is less available, which confirms the substitution effect between trade and banking/financial credit previously identified for SMEs [111,113].

The existence of a negative relationship between trade credit and GDP, and between trade credit and the employment rate, shows that the level of local development, as well as local financial development conditions, makes an importance difference to the demand for trade credit. The matching hypothesis previously verified for SMEs was also verified for MEs, particularly for bigger and older MEs (younger and smaller MEs tend to lend less trade credit to their clients than that received from suppliers). The existence of a positive relationship between trade credit in one year and in the previous year was also verified, directly in case of accounts payable, and-following the hypothesis of matching-also for account receivables.

Like previous studies $[100,102,108]$, we can also confirm the existence of a negative relationship between firm age and trade credit among Italian manufacturing MEs. This relationship, however, ceases to be negative in the mature stages due to the consolidation of business relations between suppliers and their clients.

These results were verified for green and non-green MEs in the sample, but the separate analysis of green and non-green MEs yields two important results:

1. Green MEs rely more on trade credit than non-green MEs. They offer more trade credit to their clients (the coefficient of 'accounts receivable' is much higher for green MEs than for non-green MEs). Green MEs receive more trade credit than non-green MEs ('accounts payable' in year $t$ is the dependent variable of the equation, the coefficient of 'accounts payable' in the previous year $(t-1)$ is positive, the coefficient of 'short-term bank credit' is negative, and both are higher for green MEs than for non-green MEs).

2. Age and size tend to be more important for non-green companies than for green companies: the negative relationship with trade credit is statistically significant for the non-green segment. This could mean that green MEs tend to rely on trade credit more stably and regardless of the stage of the company's life cycle.

\section{Conclusions}

Our results strongly suggest that trade credit is a much more important financial source for green than for non-green firms. This may be because the characteristics of green manufacturing processes are better known and understood by companies in the same industry. External financial intermediaries may be insufficiently regulated, and may be less well-informed about transparent criteria. The results show that trade credit supports sus- 
tainable development, and can thus help firms to improve their reputation, signaling firm quality (i.e., firms pursuing sustainable objectives) and facilitating access to banking credit for firms with high agency costs [129]. In order to increase the component of bank/financial credit for green companies and thus improve their financial inclusion, two possible steps can be outlined. On the one hand, financial intermediaries should include more specific green parameters in the assessment of the creditworthiness of MEs, and should take the entire supply chain's value into account. On the other hand, green enterprises should inform financial intermediaries of their particular characteristics more clearly due to the specific nature of the sector, as is also demonstrated by the greater importance of on-the-job training in supporting green human capital, rather than previous work experience and formal education [63]. Both steps are useful objects of future research, but they recall the importance of promoting a dialogue between different actors (companies and financial intermediaries) about the contents and the implications of the green economy for local development policies. Our results seem to suggest that, particularly in case of green companies, trade credit is a useful instrument for providing liquidity, particularly by stronger in favor of weaker firms (bigger, more profitable, and older MEs tend to offer more trade credit to their clients than that received, while smaller, less profitable, and younger MEs tend to rely more on trade credit to finance purchases than clients) [130]. To the extent that green manufacturing processes are better known and evaluated by companies belonging to the same industry, trade credit could be considered much more than a component of financial risk management policy; rather, it could be a tool for consolidating strategic long-term relationships with clients and suppliers. In this context, managers (both of the supplier and the client companies) should pay attention to the development of an effective trade credit policy (and correspondent processes) [131], properly formalized in terms of customer assessment and credit worthiness methodologies, terms and conditions (even from a legal standpoint), regular monitoring procedures (to prevent and manage delinquent accounts), and the periodical evaluation of the importance of trade credit to the value of the relationship. Finally, this study presents three main limitations. First, it concentrated on Italian manufacturing MEs; second, it relied on a specific definition of the green economy according to the above-mentioned study [122]; and third, most of the companies considered were aged over 10 years. Therefore, as future research, it would be of interest, first, to consider other industries (such as services, agriculture, alternative energies), and different sizes of business (such as small and large companies) and countries (distinguishing between Western European and Eastern European countries); second, the analysis could be further developed, taking into consideration the ways in which a different notion of green sectors (analyzing separately the single sub-components that define the definition of the green economy used in this study) could impact on the local development; and third, a different age of companies could be considered, in order to better examine the relationship between the firm's life cycle and bank/trade credit in the green economy.

Author Contributions: Conceptualization, M.C.A. and R.P.; Formal analysis, M.C.A. and R.P.; Methodology, M.C.A. and R.P.; writing-original draft preparation, M.C.A. and R.P.; writingreview and editing, M.C.A. and R.P. Both authors have read and agreed to the published version of the manuscript. All authors have read and agreed to the published version of the manuscript.

Funding: This research received no external funding.

Data Availability Statement: Some data presented in this study are available on request from the corresponding author. These data are not publicly. The data were sourced from AIDA Bureau Van Dijk database. Publicly available datasets were also analyzed in this study. This data can be found here: www.istat.it.

Conflicts of Interest: The authors declare no conflict of interest. 


\section{References}

1. IUCN-International Union for Conservation of Nature and Natural Resources. World Conservation Strategy: Living Resource Conservation for Sustainable Development; IUCN-UNEP-WWF: Gland, Switzerland, 1980. Available online: https:/ / portals.iucn. org/library/efiles/documents/wcs-004.pdf (accessed on 5 March 2021).

2. WCED—World Commission on Environment and Development. Our Common Future; WCED Report; United Nations: New York, NY, USA, 1987. Available online: https:/ / sustainabledevelopment.un.org/content/documents/5987our-common-future.pdf (accessed on 5 March 2021).

3. Pearce, D.W.; Markandya, A.; Barbier, E.B. Blueprint for a Green Economy; Earthscan: London, UK, 1989.

4. Evans, B.; Theobald, K. LASALA: Evaluating local agenda 21 in Europe. J. Environ. Plan. Manag. 2003, 46, 781-794. [CrossRef]

5. Joas, M.; Gronholm, B.; Martar, T. A comparative perspective on self-assessment of local agenda 21 in European cities. Boreal Environ. Res. 2004, 9, 499-507.

6. Barbier, E.B. Rethinking the Economic Recovery: A Global Green New Deal; Report Prepared for the Economics and Trade Branch, Division of Technology, Industry and Economics, United Nations Environment Programme; UNEP: New York, NY, USA, 2009. Available online: https:/ / www.cbd.int/development/doc/UNEP-global-green-new-deal.pdf (accessed on 5 March 2021).

7. UNEP. Towards a Green Economy: Pathways to Sustainable Development and Poverty Eradication; UNEP Report; UNEP: New York, NY, USA, 2011. Available online: https: / / sustainabledevelopment.un.org /index.php?page=view\&type=400\&nr=126\&menu=35 (accessed on 5 March 2021).

8. Caprotti, F.; Bailey, I. Making sense of the green economy. Geogr. Ann. Ser. B 2014, 96, 1-6. [CrossRef]

9. European Commission. The Inclusive Green Economy in EU Development Cooperation; Tools and Methods Series; European Commission: Bruxelles, Luxembourg, 2018. Available online: https://op.europa.eu/en/publication-detail/-/publication/a7a0 2150-01ad-11e9-adde-01aa75ed71a1/language-en/format-PDF (accessed on 5 March 2021).

10. European Commission. 2019 SBA Fact. Sheet Italy; European Union: Bruxelles, Luxembourg, 2019.

11. Kasztelan, A. Green growth green economy and sustainable development: Terminological and relational discourse. Prague Econ. Pap. 2017, 26, 487-499. [CrossRef]

12. Šipilova, V.; Ostrovska, I.; Jermolajeva, E.; Aleksejeva, L.; Oḷehnovičs, D. Evaluation of Sustainable Development in Rural Territories in Latgale Region (Latvia) by Using the Conception of Smart Specialization. J. Teach. Educ. Sustain. 2017, 19, 82-104. [CrossRef]

13. Lavrinenko, O.; Ignatjeva, S.; Ohotina, A.; Rybalkin, O.; Lazdans, D. The role of green economy in sustainable development (Case study: The EU States). Entrep. Sustain. Issues 2019, 6, 1113-1126. [CrossRef]

14. Stroebel, M. Tourism and the green Economy: Inspiring or averting change? Third World Q. 2015, 36, 2225-2243. [CrossRef]

15. Aceleanu, M.I. Sustainability and Competitiveness of Romanian Farms through Organic Agriculture. Sustainability 2016, 8, 245. [CrossRef]

16. Akhmetshina, L.; Pokrovskaya, T.; Semernin, D. Organic agriculture and sustainable development of the agrarian sector of regions in the context of "green" economy. Matec Web Conf. 2018, 193, 05047. [CrossRef]

17. Pan, S.Y.; Gao, M.; Kim, H.; Shah, K.J.; Pei, S.L.; Chiang, P.C. Advances and challenges in sustainable tourism toward a green economy. Sci. Total Environ. 2018, 635, 469-542. [CrossRef]

18. Yu, F.; Surpiyadi, A.; Wang, T.; Wang, L.; Cirella, G.T. Effects of Regional Innovation Capability on the Green Technology Efficiency of China's Manufacturing Industry: Evidence from Listed Companies. Energies 2020, 13, 5467. [CrossRef]

19. Kusakabe, E. Advancing sustainable development at the local level: The case of machizukuri in Japanese cities. Program Plann. 2013, 80, 1-65. [CrossRef]

20. Martin, D.; Evans, D. Where Are We Now? Real-Time Estimates of the Macroeconomy. Int. J. Cent. Bank. 2005, 1. [CrossRef]

21. Martinez-Fernandez, C.; Hinojosa, C.; Miranda, G. Greening Jobs and Skill: Labour Market Implications of Addressing Climate Change; Local Economic and Employment Development (LEED) Programme OECD: Paris, France, 2010. Available online: www.oecd.org/dataoecd/54/43/44683169.pdf?contentId=44683170 (accessed on 5 March 2021).

22. Consoli, D.; Marin, G.; Marzucchi, A.; Vona, F. Do green jobs differ from non-green jobs in terms of skills and human capital? Res. Policy 2016, 45, 1046-1060. [CrossRef]

23. Bruyère, S.; Filiberto, D. The green economy and job creation: Inclusion of people with disabilities in the USA. Int. J. Green Econ. 2013, 7, 257-275. [CrossRef]

24. Brown, D.; McGranahan, G. The urban informal economy, local inclusion and achieving a global green transformation. Habitat. Int. 2016, 53, 97-105. [CrossRef]

25. Unay-Gailhard, I.; Bojnec, S. The impact of green economy measures on rural employment: Green jobs in farms. J. Clean. Prod. 2019, 208, 541-551. [CrossRef]

26. Hoogma, R.; Kemp, R.; Schot, J.; Truffer, B. Experimenting for Sustainable Transport: The Approach of Strategic Niche Management; Spon Press: London, UK, 2002.

27. Caniels, M.C.J.; Romijn, H.A. Strategic niche management: Towards a policy $€$ tool for sustainable development. Technol. Anal. Strateg. Manag. 2008, 20, 245-266. [CrossRef]

28. Pitkanen, K.; Antikainen, R.; Droste, N.; Loiseau, E.; Saikku, L.; Aissani, L.; Hansjürgens, B.; Kuikman, P.J.; Leskinen, P.; Thomsen, M. What can be learned from practical cases of green economy? Studies from five European countries. J. Clean. Prod. 2016, 139, 666-676. [CrossRef] 
29. OECD. Enabling Local Green Growth. Addressing Climate Change Effects on Employment and Local Development; OECD Report; OECD: Paris, France, 2012. Available online: https:/ / www.oecd.org/cfe/leed/49387595.pdf (accessed on 5 March 2021).

30. European Commission. Annual Report on European SMEs 2018/2019; European Union: Bruxelles, Luxembourg, 2020.

31. Moro, A.; Belghitar, Y.; Mateus, C. Trade Credit in Europe: 'It Is All Down to Culture'. SSRN Electron. J. 2016. [CrossRef]

32. Meltzer, A.H. Mercantile credit, monetary policy and the size of firms. Rev. Econ. Stat. 1960, 42, 429-437. [CrossRef]

33. Brechling, F.; Lipsey, R. Trade credit and Monetary Policy. Econ. J. 1963, 73, 618-641. [CrossRef]

34. Jaffee, D.M.; Modigliani, F. A theory and Test of Credit Rationing. Am. Econ. Rev. 1969, 59, 850-872.

35. Jaffee, D.M. Credit Rationing and the Commercial Loan Market. Econ. J. 1971, 82, 758-759. [CrossRef]

36. Herbst, A.F. Some empirical evidence on the Determinants of Trade Credit at the Industry Level of Aggregation. J. Financ. Quant. Anal. 1974, 9, 377-394. [CrossRef]

37. Duca, J. Trade Credit and Credit Rationing: A Theoretical Model; Research Paper in Banking and Financial Economics 94; Board of Governors of the Federal Reserve System: Washington, DC, USA, 1986.

38. Wilner, B.S. The Exploitation of Relationship in Financial Distress: The Case of Trade Credit. J. Financ. 2007, 55, 153-178. [CrossRef]

39. Mateut, S. Trade Credit and Monetary Policy Transmission. J. Econ. Surv. 2005, 19, 655-670. [CrossRef]

40. Love, I.; Preve, L.A.; Sarria-Allende, V. Trade Credit and Bank Credit: Evidence from recent financial crises. J. Financ. Econ. 2007, 83, 469-543. [CrossRef]

41. Oliner, S.D.; Rudebusch, G.D. Monetary policy and credit conditions: Evidence from the composition of external finance: Comment. Am. Econ. Rev. 1996, 86, 300-309.

42. Gertler, M.; Gilchrist, S. The role of credit market imperfections in the monetary transmission mechanism: Arguments and evidence. Scand. J. Econ. 1993, 95, 43-64. [CrossRef]

43. Fisman, R.; Love, I. Trade credit, financial intermediary development, and industry growth". J. Financ. 2003, 58, 353-374. [CrossRef]

44. Nilsen, J. Trade credit and the bank lending channel. J. Money Credit Bank. 2002, 34, 226-253. [CrossRef]

45. Biais, B.; Gollier, C. Trade credit and credit rationing. Rev. Financ. Stud. 1997, 10, 903-937. [CrossRef]

46. Petersen, M.; Rajan, R. Trade credit: Theories and evidence. Rev. Financ. Stud. 1997, 10, 661-691. [CrossRef]

47. Pike, R.; Cheng, N.S.; Cravens, K.; Lamminmaki, D. Trade credits terms: Asymmetric information and price discrimination evidence from three continents. J. Bus. Financ. Account. 2005, 32, 1197-1236. [CrossRef]

48. Schwartz, R.A.; Whitcomb, D. The Trade Credit Decision. In Handbook of Financial Economics; Bicksler, J.L., Ed.; North-Holland: Amsterdam, The Netherlands, 1979; pp. 257-273.

49. Emery, G.W. An optimal financial response to variable demand. J. Financ. Quant. Anal. 1987, 22, 209-225. [CrossRef]

50. Freixas, X. Short Term Credit versus Account Receivable Financing; Working Paper; Universitat Pompeu Fabra: Barcelona, Spain, 1993.

51. Bukart, M.; Ellingsen, T. In-Kind Finance: A Theory of Trade. Am. Econ. Rev. 2004, 94, 569-590. [CrossRef]

52. Brennan, M.; Maksimovic, V.; Zechner, J. Vendor financing. J. Financ. 1988, 43, 1127-1141. [CrossRef]

53. Berger, A.; Udell, G. The economics of small business finance: The roles of private equity and debt markets in the financial growth cycle. J. Bank. Financ. 1988, 22, 613-673. [CrossRef]

54. Huyghebaert, N.; Van de Gucht, L.M. The determinants of financial structure: New insights from business start-ups. Eur. Financ. Manag. 2007, 13, 101-133. [CrossRef]

55. McMillan, J.; Woodruff, C. Interfirm Relationships and Informal Credit in Vietnam. Q. J. Econ. 1999, 114, 1285-1320. [CrossRef]

56. Demirgüç-Kunt, A.; Maksimovic, V. Firms as Financial Intermediaries. Evidence from Trade Credit Data; Policy Research Working Paper; WP 2696; World Bank Development Research Group: Washington, DC, USA, 2001. Available online: https: / / openknowledge.worldbank.org/handle/10986/19511 (accessed on 5 March 2021).

57. Choi, W.G.; Yungsan, K. Trade Credit and the Effect of Macro-Financial Shocks: Evidence from U.S. Panel Data. J. Financ. Quant. Anal. 2005, 40, 897-925. [CrossRef]

58. Cull, R.; Xu, L.C.; Zhu, T. Formal Finance and Trade Credit during China's Transition. J. Financ. Intermediation 2009, 18, 173-192. [CrossRef]

59. García-Teruel, P.J.; Martínez-Solano, P. Determinants of trade credit: A comparative study of European SMEs. Int. Small Bus. J. 2010, 28, 215-233. [CrossRef]

60. Carbo-Valverde, S.; Rodriguez-Fernandez, F.; Udell, G.F. Trade Credit, the Financial Crisis, and SME Access to Finance. J. Money Credit Bank. 2016, 48, 113-143. [CrossRef]

61. Garcia-Appendini, E.; Montoriol-Garriga, J. Firms as liquidity providers: Evidence from the 2007-2008 financial crisis. J. Financ. Econ. 2013, 109, 272-291. [CrossRef]

62. Ogawa, K.; Sterken, E.; Tokutsu, I. The trade credit channel revisited: Evidence from micro data of Japanese small firms. Small Bus. Econ. 2013, 40, 101-118. [CrossRef]

63. Jain, N. Monitoring Costs and Trade Credit. Q. Rev. Econ. Financ. 2001, 41, 89-110. [CrossRef]

64. Ng, C.K.; Smith, J.K.; Smith, R.L. Evidence on the determinants of credit terms used in interfirm trade. J. Financ. 1999, 54, 1109-1129. [CrossRef] 
65. Cannari, L.; Chiri, S.; Omiccioli, M. Condizioni di Credito Commerciale e Differenziazione Della Clientela; Temi di Discussione del Servizio Studi; Banca d'Italia: Rome, Italy, 2004. Available online: https://www.bancaditalia.it/pubblicazioni/temi-discussione/ 2004/2004-0495/index.html (accessed on 5 March 2021).

66. Deloof, M.; Jegers, M. Trade credit, product quality, and intragroup trade: Some European evidence. Financ. Manag. 1996, 25, 33-43. [CrossRef]

67. Lee, Y.W.; Stowe, J.D. Product risk, asymmetric information, and trade credit. J. Financ. Quant. Anal. 1993, 28, 285-300. [CrossRef]

68. Long, M.S.; Malitz, I.B.; Ravid, S.A. Trade credit, quality guarantees, and product marketability. Financ. Manag. 1993, 22, 117-127. [CrossRef]

69. Schwartz, R.A.; Whitcomb, D.K. Implicit Transfers in The Extension of Trade Credit. In Redistribution through the Financial System: The Grants Economics of Money and Credit; Bounding, E., Wilson, T.F., Eds.; Praeger Special Studies: New York, NY, USA, 1978; pp. 191-208.

70. Bougheas, S.; Mateut, S.; Mizen, P. Corporate trade credit and inventories: New evidence of a trade-off from account payable and receivable. J. Bank. Financ. 2009, 33, 300-307. [CrossRef]

71. Martínez-Sola, C.; García-Tereul, P.J. Trade credit and SME profitability. Small Bus. Econ. 2014, 42, 561-577. [CrossRef]

72. Longhofer, S.D.; Santos, J.A.C. The Paradox of Priority. Financ. Manag. 2003, 32, 69-81. [CrossRef]

73. Guiso, L.; Sapienza, P.; Zingales, L. Does local financial development matter? Q. J. Econ. 2004, 119, 929-996. [CrossRef]

74. Gagliardi, F. Financial development and the growth of cooperative firms. Small Bus. Econ. 2009, 32, 231. [CrossRef]

75. Benfratello, L.; Schiantarelli, F.; Sembenelli, A. Banks and innovation: Microeconometric evidence on Italian firms. J. financ. Econ. 2008, 90, 197-217. [CrossRef]

76. Alessandrini, P.; Presbitero, A.F.; Zazzaro, A. Banks, distances and firms' financing constraints. Rev. Financ. 2009, 13, 261-307. [CrossRef]

77. La Rocca, M.; La Rocca, T.; Cariola, A. The influence of local institutional differences on the capital structure of SMEs: Evidence from Italy. Int. Small Bus. J. 2010, 28, 234-257. [CrossRef]

78. Bonaccorsi di Patti, E.; Gobbi, G. The changing structure of local credit markets: Are small business special? J. Bank. Financ. 2001, 25, 2209-2237. [CrossRef]

79. Cassia, L.; Vismara, S. Firms' trade credit and the local level of development of the banking system in Europe. Invest. Manag. Financ. Innov. 2009, 6, 46-58.

80. Deloof, M.; La Rocca, M. Local financial development and the trade credit policy of Italian SMEs. Small Bus. Econ. 2015, 44, 905-924. [CrossRef]

81. Yazdanfar, D.; Öhman, P. The impact of trade credit use on firm profitability: Empirical evidence from Sweden. J. Adv. Res. 2016, 13, 116-129. [CrossRef]

82. Fabbri, D.; Klapper, L. Market Power and the Matching of Trade Credit Terms. World Bank Policy Research Working Paper no. 4754. 2008. Available online: https:/ / openknowledge.worldbank.org/handle/10986/6913 (accessed on 5 March 2021).

83. Bastos, R.; Pindado, J. Trade credit during a financial crisis: A panel data analysis. J. Bus. Res. 2013, 66, 614-620. [CrossRef]

84. Paul, S.; Wilson, N. The determinants of trade credit demand: Survey evidence and empirical analysis. J. Small Bus. Manag. 2007, $14,96-116$.

85. Bussoli, C. Trade Credit Financing: Substitution and Matching Effect for Italian SMEs. J. Econ. Financ. Adm. Sci. 2017, 93, 131-140.

86. Summers, B.; Wilson, N. Trade Credit Management and the Decision to Use Factoring: An Empirical Study. J. Bus. Financ. Account. 2000, 27, 37-68. [CrossRef]

87. Dedola, L.; Lippi, F. The Monetary Transmission Mechanism: Evidence from the Industries of Five OECD Countries; Temi di Discussione, No. 389; Banca d'Italia: Rome, Italy, 2000. Available online: https://www.bancaditalia.it/pubblicazioni/temi-discussione/2000 /2000-0389/index.html?com.dotmarketing.htmlpage.language=1 (accessed on 5 March 2021).

88. Guiso, L.; Kashyap, A.K.; Panetta, F.; Terlizzese, D. Will a Common European Monetary Policy have Asymmetric Effects? Temi di Discussione, No. 384; Banca d'Italia: Rome, Italy, 2000. Available online: https://www.bancaditalia.it/pubblicazioni/temidiscussione/2000/2000-0384/index.html?com.dotmarketing.htmlpage.language=1 (accessed on 5 March 2021).

89. Cuñat, V. Trade Credit: Suppliers as Debt Collectors and Insurance Providers. Rev. Financ. Stud. 2007, 20, 491-527. [CrossRef]

90. Boissay, F.; Gropp, R. Trade Credit Defaults and Liquidity Provision by Firms; Working Paper Series 753; European Central Bank: Frankfurt, Germany, 2007. Available online: https://www.ecb.europa.eu/pub/pdf/scpwps/ecbwp753.pdf (accessed on 5 March 2021).

91. Ferrando, A.; Mulier, K. Do firms use the trade credit channel to manage growth? J. Bank. Financ. 2013, 37, 3035-3046. [CrossRef]

92. Atanasova, C. Access to institutional finance and the use of trade credit. Financ. Manag. 2007, 36, 49-67. [CrossRef]

93. Casey, E.; O'Toole, C.M. Bank lending constraints, trade credit and alternative financing during the financial crisis: Evidence from European SMEs. J. Corp. Financ. 2014, 27, 173-193. [CrossRef]

94. Danielson, M.G.; Scott, J.A. Bank Loan Availability and Trade Credit Demand. Financ. Rev. 2004, 39, 579-600. [CrossRef]

95. Smith, J.K. Trade credit and informational asymmetry. J. Financ. 1987, 42, 863-872. [CrossRef]

96. Myers, S.; Majluf, N. Corporate financing and investment decision when firms have information that investors do not have. J. Financ. Econ. 1984, 13, 187-221. [CrossRef]

97. La Rocca, M.; La Rocca, T.; Cariola, A. Capital structure decisions during a firms's life cycle. Small Bus. Econ. 2011, 37, 107-130. [CrossRef] 
98. Rodríguez-Rodríguez, O.M. Trade credit in small and medium size firms: An application of the system estimator with panel data. Small Bus. Econ. 2006, 27, 103-126. [CrossRef]

99. Diamond, D. Reputation acquisition in debt markets. J. Political Econ. 1989, 97, 828-862. [CrossRef]

100. Mateut, S.; Bougheas, S.; Mizen, P. Trade credit, bank lending and monetary policy transmission. Eur. Econ. Rev. 2006, 50, 603-629. [CrossRef]

101. Taketa, K.; Udell, G.F. Lending Channels and Financial Shocks: The Case of Small and Medium-Sized Enterprise Trade Credit and the Japanese Banking Crisis. Monet. Econ. Stud. 2007, 25, 1-44.

102. Tsuruta, D. Bank loan availability and trade credit for small businesses during the financial crisis. Q. Rev. Econ. Financ. 2015, 55, 40-52. [CrossRef]

103. Canto-Cuevas, F.J.; Palacín-Sánchez, M.J.; di Pietro, F. Trade credit in SMEs: A quantile regression approach. Appl. Econ. Lett. 2016, 23, 945-948. [CrossRef]

104. Kestens, K.; Van Cauwenberge, P.; Bauwhede, H.V. Trade credit and company performance during the 2008 financial crisis. Account. Financ. 2012, 52, 1125-1151. [CrossRef]

105. McGuinness, G.; Hogan, T.; Powell, R. European trade credit use and SME survival. J. Corp. Financ. 2018, 49, 81-103. [CrossRef]

106. Niskanen, J.; Niskanen, $M$. The determinants of corporate trade credit policies in a bank dominated financial environment: The case of Finnish small firms. Eur. Financ. Manag. 2006, 12, 81-102. [CrossRef]

107. Couppey-Soubeyran, J.; Héricourtb, H. The Relationship between Trade Credit, Bank Credit and Financial Structure: From Firm-Level Non-Linearities to Financial Development Heterogeneity. A Study on MENA Firm-Level Data. Documents de Travail du Centre d'Economie de la Sorbonne. 2011. Available online: https:/ /halshs.archives-ouvertes.fr/halshs-00609625/document (accessed on 5 March 2021).

108. Matias Gama, A.P.; Van Auken, H. The interdependence between trade credit and bank lending: Commitment in intermediary firm relationships. J. Small Bus. Manag. 2015, 53, 886-904. [CrossRef]

109. Tsuruta, D. Bank information monopoly and trade credit: Do only banks have information about small business. Appl. Econ. 2008, 40, 981-996. [CrossRef]

110. Yazdanfar, D.; Öhman, P. Substitute or complement? The use of trade credit as a financing source among SMEs. Manag. Res. Rev. 2017, 40, 10-27. [CrossRef]

111. Andrieu, G.; Staglianò, R.; Van der ZwanBank, P. Bank debt and trade credit for SMEs in Europe: Firm-, industry-, and country-level determinants. Small Bus. Econ. 2018, 51, 245-264. [CrossRef]

112. Alphonse, P.; Ducret, J.; Severin, E. When Trade Credit Facilitates Access to Bank Finance: Evidence from US Small Business Data; SSRN Working Paper; University of Lille I: Lille, France, 2006.

113. McGuinness, G.; Hogan, T. Bank credit and trade credit: Evidence from SMEs over the financial crisis. Int. Small Bus. J. 2014, 34. [CrossRef]

114. Psillaki, M.; Eleftheriou, K. Trade Credit, Bank Credit, and Flight to Quality: Evidence from French SMEs. J. Small Bus. Manag. 2015, 53, 1219-1240. [CrossRef]

115. Wilson, N.; Summers, B. Trade credit terms offered by small firms: Survey evidence and empirical analysis. J. Bus. Financ. Account. 2002, 29, 317-351. [CrossRef]

116. Marotta, G. When Do Trade Credit Discounts Matter? Evidence from Italian Firm-Level Data. Appl. Econ. 2005, 37, 403-416. [CrossRef]

117. Canto-Cuevas, F.J.; Palacín-Sánchez, M.J.; Di Pietro, F. Trade Credit as a Sustainable Resource during an SME's Life Cycle. Sustainability 2019, 11, 670. [CrossRef]

118. Li, H.; Qianwei, Y.; Shanye, Y.; Hazrat, H. Trade Credit Financing and Sustainable Growth of Firms: Empirical Evidence from China. Sustainability 2019, 11, 1032. [CrossRef]

119. Istat. Annual Report 2020-The State of the Nation. 2020. Available online: https://www.istat.it/en/archivio/247100 (accessed on 5 March 2021).

120. Barbier, E.B. The green economy post Rio+20. Science 2012, 338, 887-888. [CrossRef]

121. World Bank. Inclusive Green Growth: The Pathway to Sustainable Development; World Bank Publications: Washington, DC, USA, 2012.

122. Politecnico di Milano; Camera di Commercio di Milano. Analisi dei Mercati e Delle Filiere "Green" in Lombardia; Vittorio, C., Ed.; 2012. Available online: https://www.milomb.camcom.it/c/document_library/get_file?uuid=f5241078-2624-488f-bfb7-54cc76599 d1d\&groupId=10157 (accessed on 5 March 2021).

123. Abu Bakar, L.J. Relationship between Firm Resources and Product Innovation Performance in Malaysian Small Medium Enterprises: The Moderating Role of Age and Size. Ph.D. Thesis, University Utara Malaysia, Sintok, Kedah, 2011.

124. Ayyagari, M.; Demirguc-Kunt, A.; Maksimovic, V. Small vs Young Firms Across the World: Contribution to Employment, Job Creation, and Growth; Policy Research Working Paper N. WPS 5631; World Bank: Washington, DC, USA, 2011. Available online: https: / / openknowledge.worldbank.org/handle/10986/3397 (accessed on 5 March 2021).

125. Fort, T.; Haltiwanger, J.; Jarmin, R.; Miranda, J. How Firms Respond to Business Cycles: The Role of the Firm Age and Firm Size. In Proceedings of the 13th Jacques Polak Annual Research Conference, Washington, DC, USA, 8-9 November 2012; pp. 1-65.

126. Fukuda, S.I.; Kasuya, M.; Akashi, K. The Role of trade credit for Small Firms: An Implication from Japan's Banking Crisis. J. Public Policy Rev. 2007, 3, 27-50.

127. Yang, X. The role of trade credit in the recent subprime financial crisis. J. Econ. Bus. 2011, 63, 517-529. [CrossRef] 
128. Yang, Y.; Zhang, X.; Lee, P.K. Improving the effectiveness of online healthcare platforms: An empirical study with multi-period patient doctor consultation data. Int. J. Prod. Econ. 2019, 207, 70-80. [CrossRef]

129. Atanasova, C. How do firms choose between intermediary and supplier finance? Financ. Manag. 2012, 41, 207-228. [CrossRef]

130. Rossi, M.; Giacosa, E.; Mazzoleni, A. The financing methods for small and medium companies: Comparison between Italy and Germany. Corp. Ownersh. Control. 2016, 13, 366-377. [CrossRef]

131. Rossi, M.; Lombardi, R.; Siggia, D.; Oliva, N. The impact of corporate characteristics on the financial decisions of companies: Evidence on funding decisions by Italian SMEs. J. Innov. Entrep. 2015, 5, 1-14. [CrossRef] 